\title{
Strategy of Principal Guiding as a Supervisor in Improving Teachers Performance in Al-Muslimin Junior Islamic School of Hamparan Perak
}

\author{
J.Imawan $^{1 *}$, A.M.Sibuea ${ }^{2}$, Zainuddin ${ }^{3}$ \\ \{*joimawan@gmail.com $\}$ \\ Department of Educational Administration, Medan State University, Medan, North Sumatra, \\ Indonesia ${ }^{1}$
}

\begin{abstract}
This research was intended to find out the results achieved from the implementation of the school principal guiding strategy as a supervisor to improve teachers' performance in the Al-Muslimin Junior Islamic School of Hamparan Perak. The focus of this study included: first, what was the strategy of the principal in carrying out his duties as a supervisor. Second, what factors influenced the supervision of the principal as a supervisor to improve the teacher's performance in Al-Muslimin Junior Islamic School of Hamparan Perak. This study used a naturalistic qualitative approach. The choice of this method was based on the consideration that what was sought was that it would give a picture or paint a more complex social reality in such a way that it became a concrete social phenomenon. The strategy of the principal of the Al-Muslimin Junior Islamic School of Hamparan Perak in improving teacher's performance was by supervising. The techniques in supervision were individual techniques such as class visits, class observations, personal talks and group techniques, namely discussion.
\end{abstract}

Keywords: Strategy of principal guiding, supervisors, teacher performance

\section{Introduction}

The school principal was the highest leadership in the schools and as the functional power of teacher given the additional task to lead a school in which it was organized a learning process or places where there was interaction between the teacher who gave the materials and students who receive the materials [1]. His leadership pattern will be very influential in determining the progress of the school. Soewadji Lazaruth revealed that there were three functions of the principal, namely as an education administrator, education supervisor, and education leader [2]. Therefore, in modern education the leadership of the principal was a strategic position in achieving educational goals.

Leadership in educational units always involved the efforts of a principal to influence the behavior of his subordinates. These efforts can be realized by the ability to foster, guide, supervise, control, and provide an approach to all school members, especially to the teachers. Usman's sequential leadership [3], was science and art that can influence people or groups to act as expected to achieve goals effectively and efficiently.

In Regulation of National Ministry of Education No. 13 of 2007 concerning to the Competency Standards for Principals/Islamic schools as follows: (1) managerial 
competencies, (2) entrepreneurial competencies, (3) supervisory competencies, and (4) personality competencies.

The Law of the Republic of Indonesia number 20 of 2003 concerning National Education System Chapter XI article number 39, "Educators were professionals who were tasked with planning and implementing the learning process, assessing learning outcomes, conducting guidance and training, and conducting research and community service especially for educators in college". In this case, it was emphasized that the implementation of the provisions concerning management, assessment, guidance, supervision and development of schools administered by the government was the responsibility of the government. However, it was also emphasized that principals were responsible for organizing educational activities to always hold coaching.

According to Wahjosumidjo [4] "among of education providers who must be continuously nurtured continuously by the principal were a teaching program, human resources, physical resources, cooperative relations between the principal and the community".

Based on observations and facts in the field, it was found that expectations were not in line with the reality of teacher performance in Islamic Junior High schools.

The indications were the low quality of school education results, the principal's task as supervisor, the teacher's low performance and learning activities did not run smoothly due to frequent delays and teacher absence. Administrative activities related to teaching administration such as making lesson plans not going well because there were some teachers who cannot and did not understand how to make lesson plans according to the procedure. Another indication was that there were still teachers who did not master teaching materials because before starting the learning activities the teacher did not make plans and was not in accordance with their fields.

The teachers' performance issues were not directly affected by the school leadership. Based on observations in the field it was known that the guidance carried out by the principal was not optimal. Theprincipal has not been able to serve the various needs of teachers and students, who can help and encourage teachers to carry out tasks in the administrative field.

Islamic Junior High School is a formal educational institution at the junior high school level, still very marginalized because its quality is still low compared to other educational institutions. Current development conditions of the Islamic school: (a) management management capabilities have not been as expected; (b) the level of teacher education was mostly not commensurate with the requirements set and methodological capabilities were still low; (c) the learning abilities of Islamic school teachers mostly still emphasize the introduction of cognitive concepts and have not emphasized religious behavior, social ethics and noble character [5].

Therefore, it is necessary to do a research on the strategy of Guiding School Principals as Supervisors in Improving Teacher's Performance at the Islamic Junior High School of AlMuslim of Hamparan Perak.

The purpose of this study were: (1) to find out the strategy of principal guiding towards the teacher through supervision at Islamic Junior High School of Al-Muslimin, (2) to find out the strategy of principal guiding towards teachers through supervision able to improve teacher performance at Islamic Junior High School of Al-Muslimin 3) to describe the process of principal guiding implementation strategy towards the teachers through supervision in Islamic Junior High School of Al-Muslimin, (4) to provide a positive response from the teachers to the implementation of the principal guiding strategy towards the teachers through supervision in the Islamic Junior High School of Al-Muslimin. 


\section{Methodology}

This research was carried out in the Islamic Junior High School (Madrasah Tsanawiyah Al-Muslimin Hamparan Perak) located on Jl. Chandradimuka no. 323 Klumpang Kebun subdistrict of Hamparan Perak, Deli Serdang Regency. This method was chosen based on the consideration that what was sought was that it would give a picture or paint a more complex social reality in such a way that it became a concrete social phenomenon.

\section{Result and Discussion}

\subsection{Results}

The results of researcher interviews with the school principal at the first step described the supervision of the principal from planning, implementation, follow-up supervision. In this case, the principal has been able to undergo supervision in accordance with the procedure, but there were still many obstacles that must be resolved so that the supervision of the principal can obtain satisfactory results.

To corroborate the results of research on the supervision of principals on teachers at Islamic Junior High School of Al-Muslimin at the second step of the researchers conducted interviews about supervision of the Quran Hadist teachers. Based on the interviews carried out the results showed that the principal as a supervisor meant that he should be good at researching, searching for, and determining the conditions for what was needed for the progress of his school so that the educational objectives of the school can be achieved as much as possible.

In the third step the researchers conducted interviews with teachers, regarding to the supervision of the school principal obtained the results that the principal had not provided a diverse strategy to the teachers. For this reason, the school principal needed to provide a strategy that can make supervision more attractive and not a scary thing for the teachers.

So, the learning objectives can be achieved through supervising the Islamic Junior High School principals. The techniques in supervision were numerous and varied, individual techniques, techniques were group. The techniques used by the principal of Islamic Junior High School of Al-Muslimin were class visits, observation, discussion, self-assessment, and teacher meetings.

\subsection{Discussions}

The results of the study showed that in improving the performance of Islamic Junior High School of Al-Muslimin teachers in teaching and learning activities the principal did supervision. While teacher performance was seen from the presence of the teacher, implementation of lesson plan (RPP) making, teacher assessment and the implementation of learning. The Islamic Junior High School principal directly saw the teacher's attendance list (attendance) every day so the principal could know the character of the teachers less active in teaching. The principal can hold class supervision to find out the teachers' active teaching, by supervising to help in improving the quality of teachers in implementation of RPP making because they have very effective guidance starting from making up to giving advice to teachers if they have errors in making the RPP. As for the supervision carried out by the principal towards the teacher in the preparation of the lesson plan, namely: arouse the 
awareness of the teacher in overseeing the preparation of the RPP in order to do a better job in making the RPP. The school principal supervised the course of the activity by assessing and giving input in the preparation of the RPP that was run by the teacher in order to get effective results and provided an assessment of the quality and quantity of teachers.

After doing the data triangulation, the researchers then discussed with colleagues about the supervision of the school principal. The colleagues were the people who understood about supervision with Dr. Masdar Limbong, M.Pd. He stated: In carrying out supervision, it should be done gradually every month so that the teachers' work can be carried out effectively because it has the nature of time discipline. Giving sanctions to teachers as a warning so that the teachers diligent and active in activities that existed in the school. As for the impact the role of the principal in carrying out supervision was very helpful for the teacher in carrying out his duties.

From the results of data triangulation and conversations with colleagues, researchers believed that the increase in teacher performance was very influential from the results of the supervision of theprincipal. If supervision was carried out with a strategy that fitted the needs of teachers in Islamic Junior High School of Al-Muslimin, then the teachers' performance from various aspects would be realized with satisfactory results.

\section{Conclusion}

Based on the results of the research and discussion previously stated, then in this study it can be concluded that:

a. The strategy of the head of the Islamic Junior High School of Al-Muslimin in improving teachers' performance was by supervising. The techniques in supervision were individual techniques such as class visits, class observations, personal talks and group techniques, namely discussion.

b. The performance of teachers in Islamic Junior High School of Al-Muslimin showed only social aspects while in professional and personal aspects it was not sufficient.

\section{References}

[1] Poerwadarminta, Kamus Umum Bahasa Indonesia. Jakarta: PN. Balai Pustaka, 1998.

[2] S. Lazaruth, Kepala Sekolah dan Tanggung Jawabnya. Yogyakarta: Kanisius, 1999.

[3] H. Usman, Management. Jakarta: PT. Bumi Aksara, 2013.

[4] Wahjosumidjo, Principal Leadership. Jakarta: Rajawali Pers, 2008.

[5] A. Azizy, Q \& Saleh, Madrasah dan Pendidikan Anak Bangsa. Jakarta: PT. Raja Grafindo Persada, 2004. 